\title{
Gobioides broussonnetii (Gobiidae): a new host for Pterobothrium crassicolle (Trypanorhyncha) on Marajó Island, northern Brazil
}

\author{
Gobioides broussonnetii (Gobiidae): um novo hospedeiro para Pterobothrium crassicolle (Trypanorhyncha) \\ na Ilha do Marajó, Brasil
}

\begin{abstract}
Marcela Videira ${ }^{1,2}$; Michele Velasco ${ }^{2,3}$; Lilian Dias3; Patrícia Matos ${ }^{4}$; Henrique Diniz Ferreira de Almeida Marcondes Lima da Costa ${ }^{5}$; Sérgio Carmona de Sáo Clemente ${ }^{6}$ : Edilson Matos ${ }^{3 *}$
\end{abstract}

\author{
${ }^{1}$ Departamento de Engenharia de Pesca, Universidade do Estado do Amapá - UEAP, Macapá, AP, Brasil \\ ${ }^{2}$ Programa de Pós-graduação em Biologia de Agentes Infecciosos e parasitários, Universidade Federal do Pará - UFPA, Belém, PA, Brasil \\ ${ }^{3}$ Laboratório de Pesquisa Carlos Azevedo, Universidade Federal Rural da Amazônia - UFRA, Belém, PA, Brasil \\ ${ }^{4}$ Laboratório de Pesquisa Edilson Matos, Universidade Federal do Pará - UFPA, Belém, PA, Brasil \\ ${ }^{5}$ Instituto de Geociências, Universidade Federal do Pará - UFPA, Belém, PA, Brasil \\ ${ }^{6}$ Faculdade de Veterinária, Universidade Federal Fluminense - UFF, Niterói, RJ, Brasil
}

Received April 13, 2013

Accepted June 12, 2013

\begin{abstract}
In the present study, the cestoid Pterobothrium crassicolle Diesing, 1850 (Trypanorhyncha), was observed parasitizing specimens of the violet goby (Gobioides broussonnetii Lacepède, 1800) collected from the estuary of the Paracauarí River on Marajó Island in the north of the Brazilian state of Pará, between January 2009 and December 2010. Tissue samples were analyzed, which led to identification of blastocysts containing plerocercoid larvae. These larvae were processed for scanning electron microscopy. Sixty G. broussonnetii specimens were dissected, and P. crassicolle was found in 48 (80\%) of them. The violet goby, G. broussonnetii, is a new host for P. crassicolle.
\end{abstract}

Keywords: Violet goby, plerocercus, Pterobothriidea.

\section{Resumo}

No presente estudo, o cestóide Pterobothrium crassicolle Diesing, 1850 (Trypanorhyncha) é descrito parasitando espécimes do Peixe-dragáo (Gobioides broussonnetii Lacepède, 1800), coletados no estuário do rio Paracauari na Ilha de Marajó no Norte do Estado do Pará, entre janeiro de 2009 e dezembro de 2010. Amostras de tecidos foram analisadas e blastocistos contendo larvas plerocercóides foram identificados. Estas larvas foram processadas para microscopia eletrônica de varredura. Sessenta espécimes de $G$. broussonnetii foram analisados, e $P$. crassicolle foi encontrado em 48 indivíduos (80\%). Este é o primeiro registro de P. crassicolle parasitando o Peixe-dragão, G. broussonnetii.

Palavras-chave: Peixe-dragáo, plerocercos, Pterobothriidea.

\section{Introduction}

The waters of the Amazon estuary are inhabited by both marine and freshwater fish species, which constitute an important economic resource for the region (BARTHEM, 1985). The violet goby or dragon fish, Gobioides broussonnetii Lacepède, 1800, is the largest member of the Gobiidae and forms an important link in the food chain of this estuary. It prefers muddy bays and freshwater estuaries,

*Corresponding author: Edilson Rodrigues Matos

Laboratório de Pesquisa Carlos Azevedo, Universidade Federal Rural da

Amazônia - UFRA, Av. Presidente Tancredo Neves, 2501, Montese,

CEP 66077-901, Belém, PA, Brasil

e-mail: edilson.matos9@gmail.com but is also found at sea on muddy bottoms, widely distributed around the southern USA, Central America, the Caribbean islands and northeastern South America (BRAGANÇA, 2005).

Trypanorhyncha is characterized by the presence of a bothridiumlike scolex, with reversible tentacles, with a larval, plerocercus or plerocercoid, or post-larval stage, which can be found in teleost fish, crustaceans and, occasionally, reptiles. The adults are found in the gastrointestinal tracts of elasmobranch fish (CAMPBELL; BEVERIDGE, 1994).

While these parasites are well known from studies in southern Brazil (PALM, 1997), few data are available on their occurrence 
in this country's northern (Amazon) region. The present study identifies $G$. broussonnetii as a host of Pterobothrium crassicolle in the region of Marajó Island, in the estuary of the Amazon River in northern Brazil.

\section{Materials and Methods}

Violet goby $(G$. broussonnetii) specimens $(n=60)$ were collected monthly between January 2009 and December 2010 in the area of the estuary of the Paracauarí River in the municipality of Salvaterra, which is located on Marajó Island, in the north of the Brazilian state of Pará ( $0^{\circ} 58^{\prime} \mathrm{S}$ and $\left.49^{\circ} 34^{\prime} \mathrm{W}\right)$ (MMA/ SISBIO authorization no. 27119-1). The specimens were kept in an oxygenated aquarium filled with water from the capture site, and were subsequently transported in aerated plastic bags to the Edilson Matos Research Laboratory at the Federal University of Pará (FUPA) in the mainland city of Belém. The specimens were anesthetized with MS 222 (Sandoz Laboratories) for measurement of biometric parameters and subsequent dissection.

Tissues from host samples were analyzed using a stereomicroscope, which led to identification of blastocysts containing plerocercus larvae. These larvae were processed following the procedures recommended by Eiras (1994). The taxonomic classification of the trypanorhynch helminths was based on the studies of Rego et al. (1974), Campbell and Beveridge (1994) and Palm (1997). The prevalence of the parasites and the mean intensity of infection were calculated in accordance with Bush et al. (1997).

For scanning electron microscopy (SEM), the larvae were fixed in $5 \%$ glutaraldehyde buffered with sodium cacodylate $(\mathrm{pH}$ 7.2) for 12 hours at $4{ }^{\circ} \mathrm{C}$, and then washed overnight in the same buffer solution and post-fixed in $2 \% \mathrm{OsO}_{4}$ buffered with the same solution for 3 hours at $4{ }^{\circ} \mathrm{C}$. The samples were then dehydrated in an increasing series of ethanol concentrations. The larvae were dried to the critical point, metalized with a fine $(20 \mathrm{~nm})$ layer of gold, and photographed in a LEO 1459 VP SEM operated at $80 \mathrm{kV}$. The specimens were also photographed in a Hitachi TM 3000 Tabletop electron microscope (Hitachi TM 3000), for which they were prepared following the same procedure, except for the metalization, which was not carried out in this case. Representative specimens of the species found were deposited in the Helminthological Collection of the Oswaldo Cruz Institute (CHIOC no. 37845 a-b), Rio de Janeiro, RJ, Brazil.

\section{Results and Discussion}

The $60 \mathrm{G}$. broussonnetii specimens analyzed in the present study had a mean total length of $21.7 \pm 4.5 \mathrm{~cm}$, and $48(80.0 \%)$ were found to be parasitized by at least one blastocyst, with mean intensity of 1.04. Fifty blastocysts were collected and processed, and all were identified as $P$. crassicolle, and no infections by any other helminth species were recorded. All the specimens were found in the mesentery of the fish, and it seemed that these parasites did not show any preference regarding host gender.

\section{Taxonomy:}

Superfamily Otobothrioidea Dollfus, 1942

Family Pterobothriidea Pintner, 1931

Pterobothrium crassicolle Diesing, 1850 (Figure 1a-f)

Principal morphological traits of $P$. crassicolle based on 30 plerocerci collected from $G$. broussonnetii: Plerocercus with blastocyst. Scolex elongated, acraspedote, subcylindrical and narrower than the pars bothridialis. Pars bothridialis with four piriform bothria on mobile pedicles with rounded edges (Figure 1a). Pars vaginalis is long, corresponding to more than half the length of the scolex. The tentacle sheath is initially relatively smooth, with elongated bulbs. Pars postbulbosa does not overlap the pars bothridialis. Distinctive basal armature and swelling present on bothridial and antibothridial faces of tentacle; macrohooks present on antibothridial face; asymmetrical basal swelling of tentacle present. Hook files 1 (1') widely separated, falciform; intercalary row(s) present proximally to each principal row; intercalary rows extend onto bothridial surface to merge with band of hooks occupying midline of bothridial surface of tentacle. Hooks in row 1 (1') widely spaced, falciform; hook rows interspersed with each principal hook row, the interspersed row extending along the bothridial surface bordered with the group of hooks, occupying the median line of the bothridial surface of the tentacle (Figure 1b-d). Metabasal and apical shielding formed by the principal rows of large hooks in an alternating half-spiral arrangement, heteromorphic and hollow. Small hooks interspersed between the principal rows on both the bothrial and antibothrial surfaces (Figure 1e, f).

The morphology of the $P$. crassicolle specimens collected in the present study was consistent with the descriptions provided for the species by São Clemente (1986a), Rego (1987) and Campbell and Beveridge (1996). The larvae of $P$. crassicolle are not host-specific (PORTO et al., 2009), and have been recorded in siluriform and other estuarine and marine fish species in Brazil (DIAS et al. 2011; PEREIRA Jr; BOEGER, 2005; PORTO et al., 2009; REGO, 1987; SÃO CLEMENTE, 1986a, b; SÃO CLEMENTE et al., 1997; TAKEMOTO et al., 1996).

A number of studies have recorded the presence of plerocerci of $P$. crassicolle in fish collected off the coast of Brazil. In the north of the Brazilian state of Pará, this species was recorded for the first time by Diesing (1850) (reference unexamined, apud Rego, 1987) in Bagrus marinus, and Rego (1987) provided a redescription of the species in Brachyplatystoma flavicans, B. vaillantii and B. marinus. The prevalence of infection recorded in $G$. broussonnetii was relatively high in comparison with previous studies in southern Brazil, while the intensity was comparatively low. São Clemente (1986a, b) recorded a prevalence of $11 \%$ and mean intensity of 1.52 in whitemouth croakers (Micropogonias furnieri) from Rio de Janeiro, for example, and Porto et al. (2009) recorded values of $26.7 \%$ and 2.25 , respectively, for this species from the same region (Niterói). At the southern extremity of this country, in Rio Grande, Pereira Jr. and Boeger (2005) recorded a prevalence of $66.7 \%$ and a mean intensity of infection of 5.2 in some species of sciaenid fish. The present report is the first record of $P$. crassicolle infecting the violet goby, $G$. broussonnetii. 

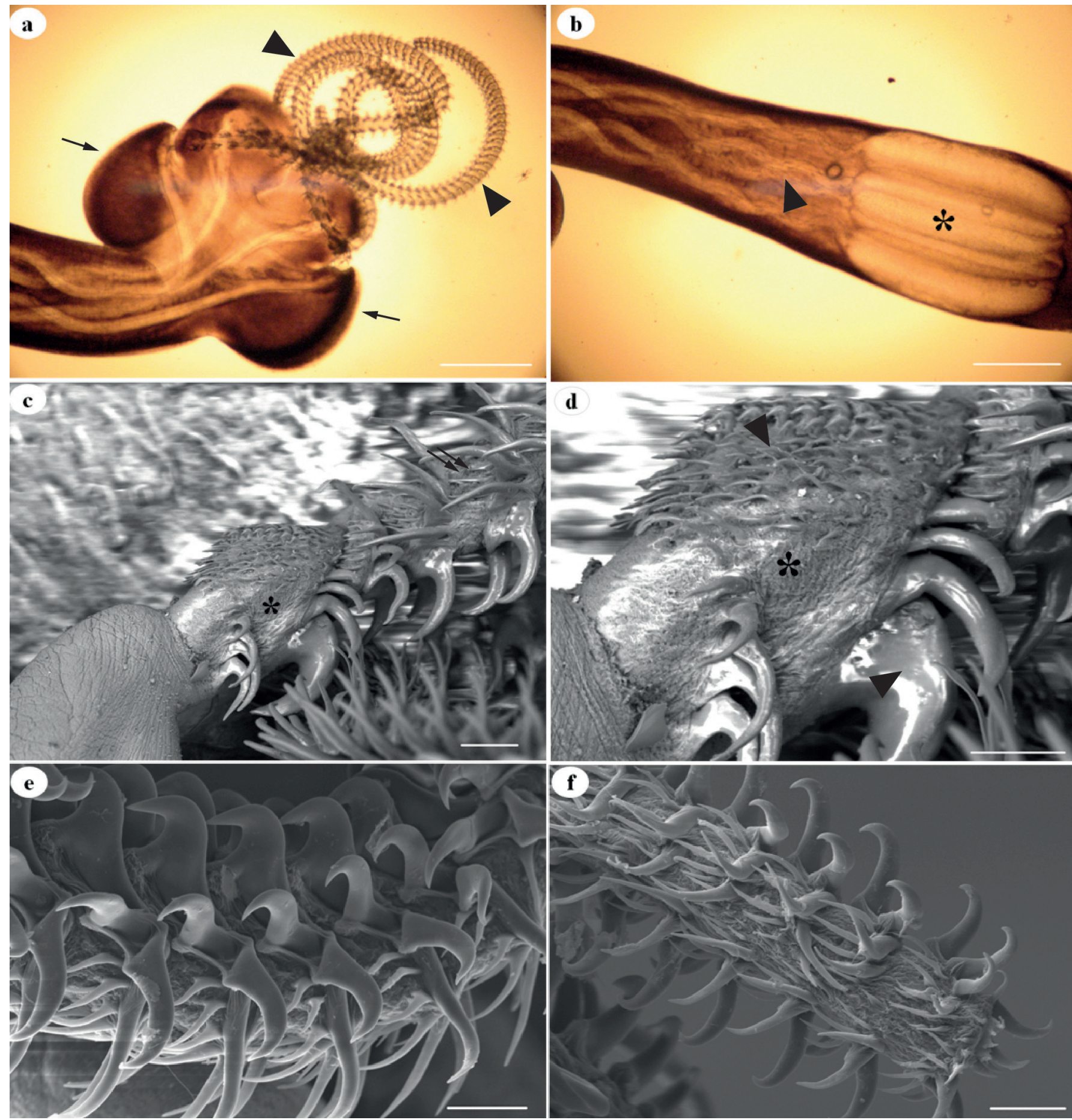

Figure 1. Pterobothrium crassicolle. (a) Optical microscopy showing the scolex with bothria (arrows) and tentacles (arrowheads). Scale bar: $500 \mu \mathrm{m}$. (b) Scolex presenting pars bulbosa $\left({ }^{*}\right)$ and tentacle sheath (arrowhead). Scale bar: $500 \mu \mathrm{m}$. (c) Tabletop electron microscopy, showing oncotaxis of the basal area of the tentacles $\left(^{*}\right)$ and the beginning of the metabasal area (double arrows). Scale bar: $40 \mu \mathrm{m}$. (d) Oncotaxis of the basal region $\left(^{*}\right)$ with hooks characteristic of the species (arrowhead). Scale bar: $30 \mu \mathrm{m}$. (e) SEM, showing oncotaxis of the metabasal region of the tentacles. Scale bar: $25 \mu \mathrm{m}$. (f) Oncotaxis of the apical region of the tentacles. Scale bar: $25 \mu \mathrm{m}$.

\section{Acknowledgements}

We are grateful to the Federal Rural University of Amazonia, Federal University of Pará, CAPES, CNPq (Edital Universal 2011),
IBAMA/ SISBIO/ICMBIO and FAPESPA, and to Dr. Stephen Ferrari for translation and revision of the manuscript. The helpful suggestions and comments of the Associate Editor and reviewers are greatly appreciated. 


\section{References}

Barthem RB. Ocorrência, distribuição e biologia dos peixes da Baía de Marajó, estuário amazônico. Bol Mus Paraense Emílio Goeldi Zool 1985; 2(1): 49-69.

Bragança AJM. Pesca, alimentação, reprodução e crescimento do Amuré, Gobioides broussonnetii Lacepède, 1800 (Pisces: Gobiidae) no Estuário Amazônico, Município de Vigia - Pará [Dissertação]. Belém: Universidade Federal do Pará; 2005.

Bush AO, Lafferty KD, Lotz JM, Shostak W. Parasitology meets ecology on its own terms: Margolis et al. Revisited. J. Parasitol 1997; 83(4): 575-583. PMid:9267395. http://dx.doi.org/10.2307/3284227

Campbell RA, Beveridge I. Order Trypanorhyncha Diesing, 1863. In: Khalil LF, Bray RA, Jones A. Keys to the cestode parasites of vertebrates. Cambridge: CAB International; 1994. p. 51-148. PMid:7988720.

Campbell RA, Beveridge I. Revision of the family Pterobothriidae Pintner, 1931 (Cestoda: Trypanorhyncha). Invertebrate Taxonomy 1996; 10(3): 617-662. http://dx.doi.org/10.1071/IT9960617

Dias LNS, Paiva RS, São Clemente SC, Rodrigues AP, Peralta ASL, Matos E. Cestóides Trypanorhyncha parasitos de Scianideos de importância comercial, capturados no litoral amazônico, Brasil. Rev Bras Cienc Vet 2011; 18(1): 3-5.

Eiras JC. Elementos de Ictioparasitologia. Porto: Ed. Fundação Eng. Antônio de Almeida; 1994.

Palm H. Trypanorhynch cestodes of commercial fishes from northeast brazilian coastal waters. Mem Inst Oswaldo Cruz 1997; 92(1): 69-79. http://dx.doi.org/10.1590/S0074-02761997000100014
Pereira Jr J, Boeger WA. Larval tapeworms (Platyhelminthes, Cestoda) from sciaenid fishes of the southern coast of Brazil. Zoosystema 2005 27(1): 5-25.

Porto CJS, São Clemente SC, Freitas MQ, São Clemente RRB, Knoff M, Matos E. Pterobothrium crassicolle (Eucestoda: Trypanorhyncha) em corvinas, Micropogonias furnieri, comercializadas no município de Niterói, Rio de Janeiro, Brasil. Rev Bras Cien Vet 2009; 16(3): 133-135.

Rego AA, Santos JC, Silva PP. Estudo de cestóides de peixes do Brasil. Mem Inst Oswaldo Cruz 1974; 72(3-4): 187-204. http://dx.doi. org/10.1590/S0074-02761974000200004

Rego AA. Redescrição de Pterobothrium crassicolle Diesing, 1850 (Cestoda: Trypanorhyncha) e revalidação de espécie. Mem Inst Oswaldo Cruz 1987; 82(1): 51-53. http://dx.doi.org/10.1590/S007402761987000100008

São Clemente SC. Plerocercos da Ordem Trypanorhyncha, parasitos de Corvina Micropogonias furnieri (Desmarest) no litoral do Estado do Rio de Janeiro. Atas Soc Biol 1986a; 26: 29-36.

São Clemente SC. Prevalência e intensidade média de infecção de plerocercos de Trypanrhyncha parasitando corvina Micropogonias furnieri (Desmarest) no litoral do Rio de Janeiro. Atas Soc Biol 1986b; 26: 37-49.

São Clemente SC, Silva CM, Gottschalk S. Prevalência e intensidade de infecção de cestóides Trypanorhyncha em anchovas, Pomatomus saltatrix (L.) do litoral Rio de Janeiro, Brasil. Parasitol día 1997; 21(1-2): 54-57.

Takemoto RM, Amato JFR, Luque JL. Comparative analysis of the metazoan parasite communities of leatherjackets, Oligoplites palometa, O. saurus and O. saliens (Osteichthyes: Carangidae) from Sepetiba Bay, Rio de Janeiro, Brazil. Rev Bras Biol 1996; 56(4): 639-650. 